JURNAL BASICEDU

Research \& Learning in Elementary Education

https://jbasic.org/index.php/basicedu

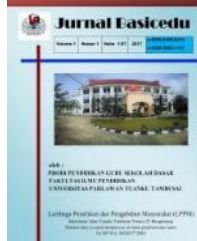

\title{
PENINGKATAN KETERAMPILAN BERPIKIR KRITIS SISWA MELALUI PENDEKATAN REALISTIK DI SEKOLAH DASAR
}

\author{
Dwi Wulan Suci ${ }^{1}$ Firman $^{2}$, Neviyarni ${ }^{3}$ \\ Universitas Negeri Padang, Sumatera Barat, Indonesia $1,2,3$ \\ Email :dwiwulansucim@gmail.com ${ }^{1}$
}

\begin{abstract}
Abstrak
Pengamatan dilakukan pada sebuah sekolah dasar yaitu di kelas $\mathrm{V}$, dengan tujuan untuk melihat efek penggunaan pendekatan realistik kepada kemampuan berpikir siswa SD. Metode yang digunakan yaitu eksperimen menggunakan dua sampel yaitu kelompok yang diajar memakai pendekatan realistik dengan tidak. Kedua kelompok diberikan tes awal berupa soal latihan yang memancing siswa berpikir kritis untuk menyelesaikan latihan. Setelah itu, salah satu kelompok diajarkan dengan pendekatan realistik. Berdasarkan hasil analisis, dapat digambarkan peningkatan keterampilan berpikir kritis matematika siswa setelah diajarkan dengan menggunakan pendekatan realistik. Siswa dapat menghubungkan rumus-rumus, angka-angka dalam matematika untuk penyelesaian masalah sehari-hari. Di samping itu siswa lebih bersemangat dan termotivasi belajar dengan menggunakan pendekatan realistik.
\end{abstract}

Kata Kunci: matematika, realistik

\begin{abstract}
Observations were made at an elementary school in class $\mathrm{V}$, with the aim to see the effect of a realistikmathematics approach to mathematics. The method used is an experiment using two samples, i.e. group taught using a realistic approachwith no. Both groups were given a preliminary test in the form of practice questions that provoked student to think critically to complete the exercise. After that, one group is taughts with a realistic approach. Based on the results of the analysis can be described an increase in students critical mathematical thinking skills after being taught using a realistic approach. Students can connect formulas in numerical formulas to solve everyday problems. Besides that students are more excited and motivated to learn by using a realistik approach.
\end{abstract}

Keywords : mathematic,realistik

@ Jurnal Basicedu Prodi PGSD FIP UPTT 2019

Corresponding author :

Address :

ISSN 2580-3735 (Media Cetak)

Email :

ISSN 2580-1147 (Media Online)

Phone : 
2043 Peningkatan keterampilan berpikir kritis siswa melalui pendekatan realistik di sekolah dasar - Dwi Wulan Suci, Firman, Neviyarni

\section{PENDAHULUAN}

Pembelajaran matematika sepertinya menjadi hal yang kurang disukai oleh siswa sekolah dasar. Apalagi saat siswa diminta mengerjakan latihan soal berupa soal cerita dan membutuhkan penalaran, pemahaman dalam menyelesaikannya. Jika siswa dihadapkan pada soal yang berupa isian singkat seperti contoh mencari luas sebuah bangun datar yang panjang dan lebar persegi panjang diketahui adalah 10 dan 5. Siswa berpacu untuk menyelesaikannya karena mereka sudah mempelajari bahwa untuk mencari nya tersebut sama dengan panjang di kali lebar. Namun ketika mereka dihadapkan pada soal cerita yang penyelesaiannya memerlukan penalaran dan logika, siswa mulai kesulitan.

Bahkan terkadang siswa kaya akan konsep dalam Pembelajaran matematika namun miskin aplikasi, sehingga matematika dirasa kurang berarti bagi siswa. Padahal dalam kehidupan sehari-hari banyak sekali permasalahan yang penyelesaiannya membutuhkan simbol-simbol dan teorema dalam matematika. Dan terkadang siswa ingin bertanya kepada guru, namun mereka tidak mengetahui apa yang akan mereka tanyakan.

Kemampuan berpikir kritis siswa belum terasah dalam matematika karena guru hanya mengajarkan matematika secara konvensional. Karena pada hakikatnya Pembelajaran matematika tersebut dapat memancing siswa lebih aktif, mengembangkan kemampuan penalaran dan berpikir siswa dan dapat memahami masalah secara sistematis, berkomunikasi, mencari data, mengolah dan menyimpulkan.

berpikir kritis erat kaitan nya dengan kemampuan yang dimiliki oleh sesorang untuk dapat memahami, mencari data, mengkomunikasikan, mencari solusi pemecahan dan dapat mengomunikasikan masalah tersebut (Saefudin : 2012).

Keterampilan berpikir kritis sangat besar pengaruhnya bagi kehidupan dalam menjalani era 4.0. Namun terkadang kemampuan berpikir kritis ini belum menjadi yang utama dalam pembelajaran matematika di sekolah dasar.

Fruner (dalam Karim : 2011), menjelaskkan bahwa keterampilan berpikir kritis tersebut didapatkan dari Pembelajaran yang menggunakan berbagai pendekatan yang terorganisis.

Jadi keterampilan berpikir kritis tersebut tidak serta merta didapatkan, namun melalui suatu proses pembelajaran yang dapat mengasah kemampuan berpikir, pembelajaran yang melatih kemampuan mengkomunikasikan ide atau gagasan yang timbul.

Menurut Ruseffendi (dalam usdiyana : 2009) menyatakan bahwa pembelajaran yang menggunakan penedekatan matematika realistik dapat membiasakan siswa untuk berpikir secara kritis. Sesuai dengan karakteristik yang dimiliki oleh pendekatan matematika realistik.

Jadi keterampilan berpikir kritis pada siswa dapat di biasakan melalui pembelajaran realistik, karena pembelajaran realistik membawa siswa pada kondisi atau situaasi yang dekat dengan kehidupan siswa, sehingga pendekatan matematika realistik tepat digunakan dalam pembelajaran matematika di sekolah dasar untuk mengembangkan keterampilan berpikir siswa.

Siswa yang terbiasa belajar dengan pendekatan realistik akan mengalami proses berpikir dan penalaran yang bagus. Siswa akan terbiasa dilatih memahami permasalahan yang erat kaitannya dengan kehidupannya, siswa juga dilatih bagaimana menganalisis permasalahan tersebut, mencari solusi dari penyelesaian masalah dan dapat mengambil kesimpulan permasalahan tersebut dan dapat menyampaikan solusi penyelesaian masalah kepada orang lain. 
2044 Peningkatan keterampilan berpikir kritis siswa melalui pendekatan realistik di sekolah dasar - Dwi Wulan Suci, Firman, Neviyarni

Sesuai dengan prinsip dari pendekatan

Setelah itu peneliti memberikan tes akhir matematika realistik yang disampaikan oleh Gravemeijer (dalam Holisin : 2007), pembelajaran matematika tersebut membuat siswa mengalami proses menemukan kembali, menggunakan berbagai model yang menurut mereka cocok dan menemukan sendiri penyelesaian dari masalah.

Merujuk dari latar belakang yang telah dikemukakan, penulis ingin mangkaji bagaimana pengaruh pendekatan matematika realistik terhadap keterampilan berpikir kritis siswa sekolah dasar. Yang mengkaji bagaimana siswa sekolah dasar dapat menyelesaikan permasalahan yang ditemuinya dalam kehidupan.

\section{METODE PENELITIAN}

Sesuai dengan langkah sebuah penelitian eksperimen, peneliti menggunakan sampel sebanyak 50 orang yang terdiri dari dua kelompok siswa. Kelompok satu, siswa yang diajar dengan pendekatan realistik dengan yang tidak atau menggunakan matematika biasa dan kelompok dua, kelompok siswa yang diajar dengan menggunakan matematika realistik.

Kelompok siswa:

$\mathrm{X}$ : tidak dapat tindakan

Y : dapat tindakan

Perlakuan diberikan yaitu pembelajaran yang dilakukan dengan menggunakan pendekatan realistik.

Pengamatan dilakukan dengan memberikan tes awal kepada kedua kelompok tersebut sebelum diberikan perlakuan apapun. Peneliti memberikan 10 buah soal cerita yang memerlukan keterampilan berpikir kritis untuk mengerjakannya, Setelah itu peneliti menganalisis hasil kerja masing-masing siswa.

Setelah itu peneliti memberikan perlakuan pada salah satu kelompok yaitu pengajaran matematika dengan realistik. Peneliti melakukan pengamatan mengenai pengalaman siswa belajar matematika dengan menggunakan pendekatan realistik.

kepada kelompok yg dapat tindakan dan tidak guna melihat keterampilan berpikir kritis siswa dalam menyelesaikan soal cerita tersebut. Dengan menganalisis kertas kerja siswa.

Setelah itu, peneliti membandingkan ratarata- rata hasil kerja siswa yang dapat tindakan dan tidak.

Bagan 1

Bagan Alur Penelitian

Alur yang digunakan pada penelitian antara lain :

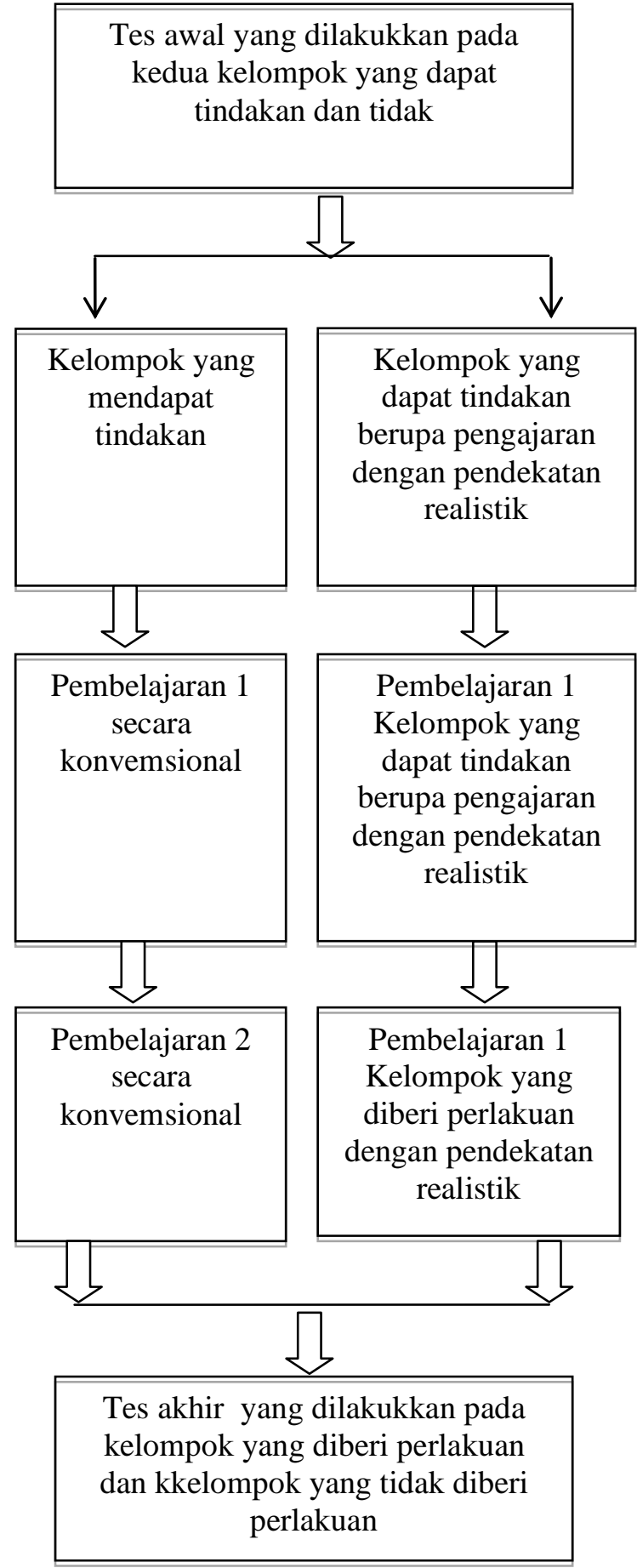


2045 Peningkatan keterampilan berpikir kritis siswa melalui pendekatan realistik di sekolah dasar - Dwi Wulan Suci, Firman, Neviyarni

masing-masing melaksanakan pembelajaran

2. Nilai siswa kelompok Y : Yaitu kelompok matematika sebanyak dua kali pembelajaran. Kelompok yang tidak mendapat tindakan pengajaran realistik belajar secara biasa.

Sedangkan yang dapat tindakan pengajaran dengan pendekatan matematika realistik. Diakhir pembelajaran 2 masing - masing kelompok diberikan tes akhir. Untuk melihat perbandingan berpikir kritis siswa yang menggunakan pendekatan matematika realistik dengan kelompok siswa yang hanya diajarkan secara konvensional.

\section{HASIL DAN PEMBAHASAN}

Berdasarkan pengamatan tes awal yang dilakukan kepada dua kelompok tersebut didapatkan hasil belajar di kelompok yang tidak mendapat tindakan dan yang dapat tindakan dengan menggunakan pendekatan matematika realistiksebagai berikut :

Tabel 1

Hasil Tes Awal yang diberi tindakan dan yang tidak

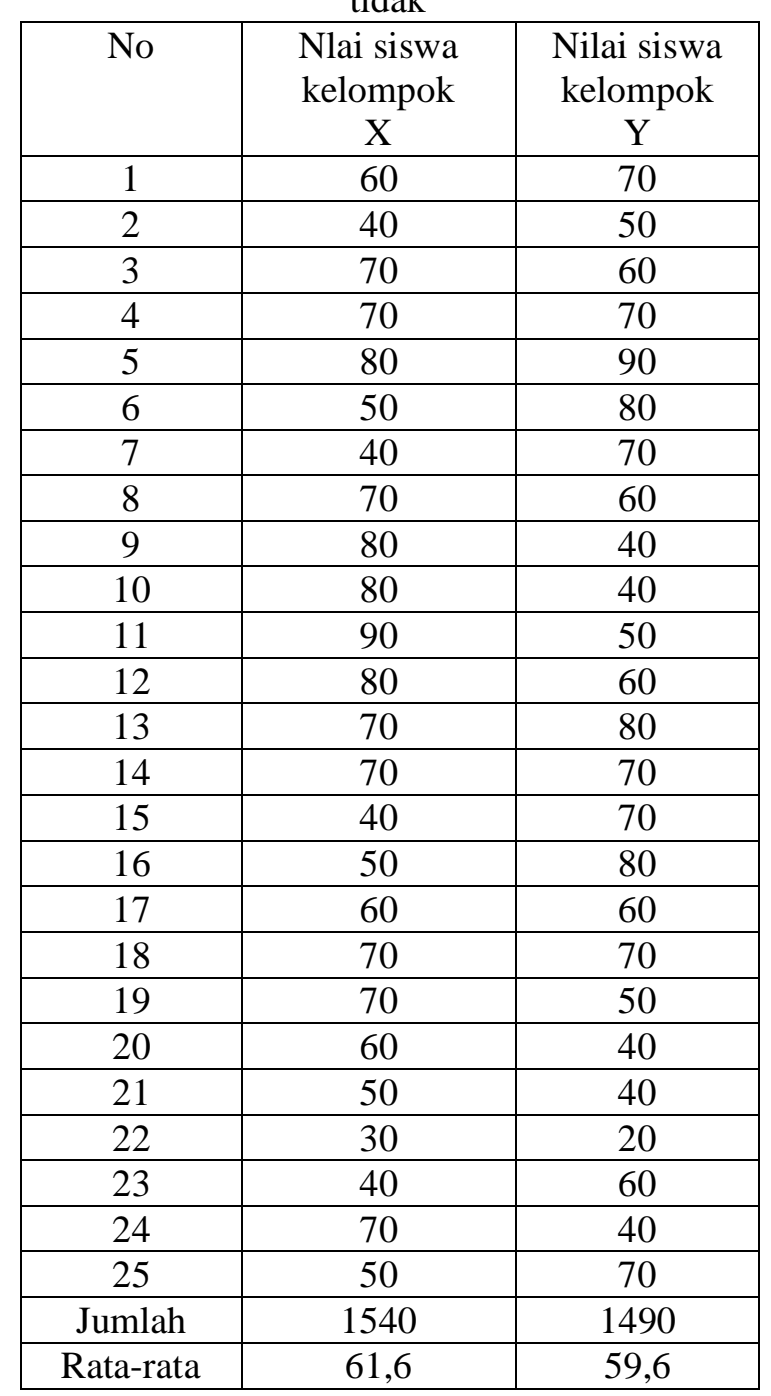

Keterangan

1. Nilai siswa kelompok $\mathrm{X}$ : Yaitu kelompok siswa yang tidak di beri tindakan apapun 
2046 Peningkatan keterampilan berpikir kritis siswa melalui pendekatan realistik di sekolah dasar - Dwi Wulan Suci, Firman, Neviyarni

menggunakan pendekatan realistik, kelompok $\mathrm{X}$ diberikan pembelajaran dengan memberikan siswa rumus-rumus matematika, simbol-simbol dalam matematika. Kemudian siswa mengerjakan latihan soal cerita dengan menggunakan rumus dan simbol tersebut. Pembelajaran dilaksanakan sebanyak 2 kali pembelajaran. Dari pengamatan peneliti, siswa Kesulitan dalam mengerjakan soal tersebut, sehingga suasana kelas menjadi ribut, anak tidak antusias belajar. Pekerjaan siswa cenderung tidak selesai.

Setelah selesai melaksanakan pengamatan terhadap pengajaran di setiap kelompok, diadakanlah uji akhir guna melihat pengaruh perlakuan yang diberikan terhadap keterampilan berpikir kritis siswa dalam mengerjakan soal yang erat kaitannya terhadap masalah-masalah yang ditemui dalam kehidupan dan untuk menyelesaikannya diperlukan matematika.

Tabel 2

Hasil pembelajaran 1 dan 2 serta tes akhir Kelompok yang tidak diberikan perlakuan (X)

\begin{tabular}{|c|c|c|c|}
\hline \multirow[t]{2}{*}{ No } & \multicolumn{2}{|c|}{ Pembelajaran } & \multirow{2}{*}{$\begin{array}{c}\text { Hasil } \\
\text { tes } \\
\text { akhir }\end{array}$} \\
\hline & 1 & 2 & \\
\hline 1 & 20 & 40 & 70 \\
\hline 2 & 40 & 60 & 60 \\
\hline 3 & 80 & 60 & 50 \\
\hline 4 & 60 & 60 & 80 \\
\hline 5 & 80 & 80 & 90 \\
\hline 6 & 40 & 20 & 70 \\
\hline 7 & 20 & 40 & 60 \\
\hline 8 & 60 & 80 & 70 \\
\hline 9 & 80 & 60 & 50 \\
\hline 10 & 60 & 60 & 80 \\
\hline 11 & 100 & 100 & 90 \\
\hline 12 & 40 & 60 & 30 \\
\hline 13 & 60 & 60 & 70 \\
\hline 14 & 80 & 60 & 70 \\
\hline 15 & 80 & 80 & 90 \\
\hline 16 & 60 & 60 & 70 \\
\hline 17 & 40 & 40 & 50 \\
\hline 18 & 60 & 20 & 70 \\
\hline 19 & 60 & 40 & 60 \\
\hline 20 & 80 & 100 & 80 \\
\hline 21 & 40 & 80 & 50 \\
\hline 22 & 60 & 60 & 50 \\
\hline 23 & 60 & 60 & 60 \\
\hline 24 & 80 & 60 & 60 \\
\hline 25 & 40 & 60 & 60 \\
\hline Jumlah & 1.480 & 1.500 & 1.640 \\
\hline Rata-rata & 59,5 & 60 & 65,6 \\
\hline
\end{tabular}

Persentase ketuntasan siswa :

1. Pembelajaran 1 :

Siswa yang tuntas : 8 orang

Persentase ketuntasan

$(8: 25) \times 100=32 \%$

2. Pembelajaran 2

Siswa yang tuntas

: 6 orang

Persentase ketuntasan

$(6: 25) \times 100=24 \%$

3. Tes Akhir

Siswa yang tuntas

: 6 orang

Persentase ketuntasan

$(6: 25) \times 100=24 \%$

Dari tabel 2 mengenai hasil pelaksanaan pembelajaran matematika pada kelompok X dapat dilihat pembelajaran 1 hanya 8 siswa tuntas, pada pembelajaran 2 hanya 6 . pada pembelajaran 1 dan 2 tidak meningkat dibanding hasil tes awal yang telah dilakukan melainkan mengalami penurunan dari hasil tes awal.

Rata hasil uji akhir pada kelompok X alami penurunan dibanding hasil tes awal. Hanya 6 siswa yang tuntas dalam pengajaran tersebut. Persentase tuntas siswa hanya mencapai $24 \%$. Hal tersebut tentu sangat jauh dari yang diharapkan oleh sekolah.

Sedangkan untuk kelompok Y, Mereka diberi Tindakan pengajaran menggunakan pendekatan matematika realistik. Pembelajaran dilaksanakan sebanyak dua kali pembelajaran. Dari pengamatan di lapangan siswa semangat belajar matematika, ketika menyelesaikan soal matematika yang dekat dengan kehidupan yang dialaminya. siswa terlihat tidak kesulitan menyelesaikannya.

Pada kelas Y pembelajaran dihadapkan pada situasi nyata, siswa diberikan benda-benda konkrit untuk menyelesaikan masalah. Karena pada asarnya siswa sekolah dasar lebih cepat mengerti apabila dihadapkan pada situasi yang benar-benar nyata. Mereka dapat menghubungkan antara konsep angka dan rumus serta simbol dalam 
2047 Peningkatan keterampilan berpikir kritis siswa melalui pendekatan realistik di sekolah dasar - Dwi Wulan Suci, Firman, Neviyarni

pembelajaran matematika tersebut untuk menyelesaikan persoalan yang pemecahannya memerlukan teori matematika itu sendiri.

Pada kelompok Y Ssswa digiring menemukan solusi permasalahan dengan real dan situasi yang nyata. Hasil pembelajaran 1, 2 dan hasil akhir siswa kelompok Y yang diberikan perlakuan dengan menggunakan pendekatan matematika realistik dapat dilihat dalam tabel 3 sebagai berrikut:

Tabel 3

Uji pembelajaran 1 dan 2 serta tes akhir Kelompok yang diberikan perlakuan dengan pendekatan realistik

(Y)

\begin{tabular}{|c|c|c|c|}
\hline \multirow[t]{2}{*}{ No } & \multicolumn{2}{|c|}{ Pembelajaran } & \multirow{2}{*}{$\begin{array}{c}\text { Hasil } \\
\text { tes } \\
\text { akhir }\end{array}$} \\
\hline & 1 & 2 & \\
\hline 1 & 80 & 80 & 100 \\
\hline 2 & 80 & 80 & 100 \\
\hline 3 & 100 & 100 & 100 \\
\hline 4 & 60 & 80 & 80 \\
\hline 5 & 100 & 80 & 90 \\
\hline 6 & 100 & 100 & 80 \\
\hline 7 & 80 & 60 & 100 \\
\hline 8 & 60 & 80 & 90 \\
\hline 9 & 60 & 80 & 70 \\
\hline 10 & 60 & 80 & 80 \\
\hline 11 & 80 & 80 & 80 \\
\hline 12 & 80 & 100 & 100 \\
\hline 13 & 80 & 100 & 100 \\
\hline 14 & 40 & 40 & 60 \\
\hline 15 & 80 & 80 & 70 \\
\hline 16 & 80 & 60 & 80 \\
\hline 17 & 80 & 100 & 100 \\
\hline 18 & 100 & 100 & 100 \\
\hline 19 & 60 & 60 & 80 \\
\hline 20 & 60 & 80 & 80 \\
\hline 21 & 80 & 80 & 100 \\
\hline 22 & 60 & 80 & 70 \\
\hline 23 & 80 & 80 & 100 \\
\hline 24 & 100 & 100 & 100 \\
\hline 25 & 80 & 80 & 80 \\
\hline Jumlah & 1.920 & 2.040 & 2.190 \\
\hline Rata-rata & 76,8 & 81,6 & 87,6 \\
\hline
\end{tabular}

Persentase ketuntasan siswa :

1. Pembelajaran 1 :

Siswa yang tuntas

Persentase ketuntasan

$(17: 25) \times 100=68 \%$

2. Pembelajaran 2

Siswa yang tuntas

: 21 orang

Persentase ketuntasan

$(21: 25) \times 100=84 \%$

3. Tes Akhir

Siswa yang tuntas

:21 orang

Persentase ketuntasan

$(21: 25) \times 100=84 \%$

Dari tabel 3 mengenai hasil pelaksanaan pembelajaran matematika pada kelompok Y yang diberikan perlakuan berupa Pembelajaran dengan pendekatan realistik, dapat dilihat pada pembelajaran 1 sebanyak 17 orang tuntas, dan pada pembelajaran 2 sebanyak 21 orang yang tuntas, rata - rata pada pembelajaran 1 dan 2 mengalami peningkatan. Rata-rata uji akhir pada kelompok Y juga naik dari hasil tes pembelajaran 1 dan 2 pada kelompok Y.

Persentase ketuntasan pada kelompok Y pada Pembelajaran 2 mengalami peningkatan dari pembellajaran 1 dan pada tes akhir juga mengalami peningkatan dari pada Pembelajaran 1 dan 2.

Pada kelompok Y, siswa lebih terlihat serius mengerjakkan latihan. Mereka lebih bersemangat belajar. Lebih gembira dan lebih mengembangkan nalar matematika. Hanya beberapa siswa yang terlihat kurang bersemangat. Melalui Pembelajaran dengan pendekatan realistik, siswa diajak lebih mengembangkan logika mereka dalam pencarian solusi pemecahan masalah yang melibatkan matematika.

Siswa tidak kesulitan mengaplikasikan kegiatan konkrit, semi konkrit dan abstrak dalam menyelesaikan soal cerita. Pembelajaran menggunakan pendekatan realistik bisa membuat siswa yang pasif menjadi lebih aktif. Siswa juga diajarkan untuk melakukan belajar dalam kelompok, guru juga mengontrol siswa melakukan penyelidikan baik secara individual ataupun bersama untuk memcahkan soal cerita. Kemudian 
2048 Peningkatan keterampilan berpikir kritis siswa melalui pendekatan realistik di sekolah dasar - Dwi

Wulan Suci, Firman, Neviyarni

siswa juga dituntun untuk menyelesaikan masalah secara sistematis dan terorganisir.

Perbandingan antara kelompok $\mathrm{X}$ dan $\mathrm{Y}$ terletak pada pemberian perlakuan, kelompok $\mathrm{X}$ yang tidak mengalami perlakuan tidak memperlihatkan peningkatan pada keterampilan berpikirnya sedangkan pada Kelompok Y yang mendapatkkan perlakuan terlihat peningkatan yang sangat berarti pada keterampilan berpikir siswa. Perbandingan tersebut dapat digambarkan dalam tabel:

Tabel 4

Perbandingan uji awal dan akhir

\begin{tabular}{|c|c|c|c|c|}
\hline \multirow{2}{*}{ No } & \multicolumn{2}{|c|}{ Awal } & \multicolumn{2}{c|}{ Akhir } \\
\cline { 2 - 5 } & X & Y & X & Y \\
\hline 1 & 60 & 70 & 70 & 100 \\
\hline 2 & 40 & 50 & 60 & 100 \\
\hline 3 & 70 & 60 & 50 & 100 \\
\hline 4 & 70 & 70 & 80 & 80 \\
\hline 5 & 80 & 90 & 90 & 90 \\
\hline 6 & 50 & 80 & 70 & 80 \\
\hline 7 & 40 & 70 & 60 & 100 \\
\hline 8 & 70 & 60 & 70 & 90 \\
\hline 9 & 80 & 40 & 50 & 70 \\
\hline 10 & 80 & 40 & 80 & 80 \\
\hline 11 & 90 & 50 & 90 & 80 \\
\hline 12 & 80 & 60 & 30 & 100 \\
\hline 13 & 70 & 80 & 70 & 100 \\
\hline 14 & 70 & 70 & 70 & 60 \\
\hline 15 & 40 & 70 & 90 & 70 \\
\hline 16 & 50 & 80 & 70 & 80 \\
\hline 17 & 60 & 60 & 50 & 100 \\
\hline 18 & 70 & 70 & 70 & 100 \\
\hline 19 & 70 & 50 & 60 & 80 \\
\hline 20 & 60 & 40 & 80 & 80 \\
\hline 21 & 50 & 40 & 50 & 100 \\
\hline 22 & 30 & 20 & 50 & 70 \\
\hline 23 & 40 & 60 & 60 & 100 \\
\hline 24 & 70 & 40 & 60 & 100 \\
\hline 25 & 50 & 70 & 60 & 80 \\
\hline Jumlah & 1540 & 1490 & 1.640 & 2.190 \\
\hline Rata-rata & 61,6 & 59,6 & 65,6 & 87,6 \\
\hline
\end{tabular}

Dari tabel dapat terlihat siswa yang

mempunya kemampuan berimbang pada saat pada saat awal sebelum ada kelompok yang diberi perlakuan, setelah diberikan perlakuan ternyata berpengaruh kepada nilai siswa.

Kelompok yang dapat perlakuan berupa pengajaran dengan realistik, mempunyai dampak yang sangat bagus dalam meningkatkan keterampilan siswa memainkan logika dan nalar mereka, kemampuan berpikir kritis siswa juga turut terasah dengan Pembelajaran realistik.

Siswa jadi tahu guna rumus, algoritma, simbol, angka, algoritma itu untuk pemecahan masalah, karena mereka menemui situasi yang nyata tersebut dalam pembelajaran.

Selanjutnya, Terima kasih diucapkan kepada yang turut serta membantu penulisan artikel dan kepada seluruh tim jurnal basicedu yang telah membantu Dalam penerbitan artikel ini.

\section{KESIMPULAN}

Berdasarkan penggamatan dan penelitian yang telah dilakukan dapat disimpulkan bahwa Pembelajaran yang dilaksanakan dengan pendekatan realistik memberikan pengaruh yyang cukup signifikan terhadap proses berpikir siswa. Yang dapat dilihat dari hasil belajar siswa.

Siswa menjadi terlatih menyelesaikan soal cerita secara sistematis dan terorganisir. Peningkatan tersebut dapat telihat dalam uji kemampuan awal dan akhir siswa dalam mengerjakan soal. Siswa mulanya punya kemampuan matematik yang sama, usai diberikan tindakan yang berbeda mengalami peningkatan pada aspek berpikir kritisnya.

Disamping itu, siswa juga terlihat semakin aktif, termotivasi dalam belajar jika diajarkan dengan pendekatan matematika realistik. Saran yang dapat diberikan kepada guru hendaknya dapat menerapkan strategi, model, dan pendekatan yang lebih bervariasi dalam Pembelajaran, agar siswa lebih antusias dalam belajar. 
2049 Peningkatan keterampilan berpikir kritis siswa melalui pendekatan realistik di sekolah dasar - Dwi Wulan Suci, Firman, Neviyarni

\section{DAFTAR PUSTAKA}

Holisin,iis (2007). Pembelajaran Matematikarealistik:Didaktis, Vol 5(3), hal 4549

Karim, A (2011). Penerapan Metode Penemuan Terbimbing dalam Pembelajaran Matematika Untuk Meningkatkan Pemahaman Konsep Dan Kemampuan berpikir Kritis Siswa Sekolah Dasar . Jurnal Penelitian Pendidikan, vol 1 (2) hal 154-163

Saefuddin, A (2012). Pengembangan Kemampuan berpikir Kreatif Siswa dalam Pembelajarn Matematika dengan Pendekatan Matematika realistikIndonesia. Vol 4(1) Hal 37-48

Usdiyana, D, dkk (2009). Meningkatkan Kemampuan berpikir Logis Siswa Melalui Pembelajaran Matematikarealistik. Jurnal Pengajaran Matematika dan Ilmu Pengetahuan Alam, Vol 13(1) hal 11-20 